\title{
EFFECT OF EXCHANGE RATE VOLATILITY ON EXPORTS IN NIGERIA: A TEST OF COCHRANE-ORCUTT TECHNIQUE
}

\author{
Bello Malam Sa'idu ${ }^{1}$ \\ ${ }^{\prime}$ Department of Economics and Development Studies, Faculty of Arts and Social Sciences, Federal University Dutse, Jigawa State, \\ Nigeria
}

\begin{abstract}
This paper examines the dynamic effects of exchange rate fluctuations on exports in Nigeria. To achieve the set objectives, classical least square and Cochrane-Orcutt technique were applied. Results revealed that exchange rate volatility and foreign income have positive and significant effect on exports, while relative prices exert negative and significant effect on exports. This implies that, a unit rise in exchange rate volatility and foreign income, coincidentally both lead to increase in exports by eightfold. Consequently, government should strengthen the Naira to minor spirals, attract foreign income flow, and promote export goods, among others. Foreign income flow could be attracted via private investment of export goods, transforming them to semi-processed form thereby improving exports prices, values and volume in the country.
\end{abstract}

Keywords: Exports, Fluctuations, Exchange rate, Volatility, Cochrane-Orcutt technique.

Jel Classification: F1, E3, C22, C5, O5.

Received: 19 January 2015/ Revised: 2 March 2015/ Accepted: 10 March 2015/ Published: 18 March 2015

\section{Contribution/ Originality}

This study contributes to existing literature in terms of exchange rate volatility on exports. It uses modified version of existing methodologies. Also, the paper's primary contribution is finding that, exchange rate volatility and foreign income have positive and significant effect on exports, which both raises aggregate trade by eightfold.

\section{INTRODUCTION}

The floating exchange rate has been in existence since the breakdown of Bretton Woods's system of fixed exchange rate in the 1970s, between those periods, the Naira to US Dollar exchange rate was relatively steady with the Naira value being greater than US Dollar up to 
1985. In Nigeria, since the introduction of structural adjustment programme (SAP) in 1986, it was a downturn for the Naira currency and it has been weaken unabatedly causing changes in major macroeconomics variables. SAP has made exchange rate to be highly volatile on the volume of international trade flow and these has been the subject of theoretical and empirical discourse.

The Naira exchange rate was fairly stable from 1970 to 1985 but by mid-1986 it depreciated to about N22 per $\$ 1$ due to SAP implemented by the then Ibrahim Babangida regime, following World Bank/IMF conditionalities. The Central Bank of Nigeria (CBN) intervened six times in the autonomous foreign exchange market (AFEM) in 1995 to rescue the situation and was able to get $\$ 1.748$ billion to meet the demand of the foreign exchange market (FOREX). As a result of this, the AFEM and the parallel market rates (PMR) were relatively stabilized with two rates: N82.3:\$1 and N83.7:\$1. But, by 1996 the CBN maintained dual exchange rates: N22 to $\$ 1$ as official and N82.5 to $\$ 1$ as AFEM rate (see CBN (2013)). Moreover, all the changes in exchange rate market name, i.e. from AFEM to interbank foreign exchange market (IFEM) and Dutch Auction System (DAS) does not revalue the Naira currency vis-à-vis other World currencies, even the bureau-de-change rate (BDC) followed the same fashion, yet higher than the DAS. The depreciation and high volatility clustering of Naira continued unabated.

It is these facts, that gave emphasis to the importance of exchange rate to the economic interest of Nigeria, as it doors to international trade are widely open to goods and services. Exchange rate volatility affects the bond of price systems of countries making global trade to slow down. Thus, exchange rate links domestic prices with global prices via its effects on the volume of imports and exports, it also exerts a powerful influence on a country's macroeconomics variables. According to Doroodian (1999) and Krugman (1989) increase risk associated with exchange rate volatility induces risk-averse agents to re-direct their resources to riskless economic activities. Hence, in line with risk aversion hypothesis export may be negatively correlated with exchange rate volatility. However, standard exchange rate volatility models do hypothesize a long run relationship between exchange rate and various set of macroeconomics variables; it is more often expressed in a log-linear reduced form (Goldberg and Fryman, 1993).

There has been growing literature on the extent of exchange rate and its misalignment (Soludo and Adeola, 1997; Obaseki, 2001; CBN, 2012; Elbadawi et al., 2012) but very few empirical works found that studied exchange rate volatility on exports. Hence, the needs for more studies like this. To study the short-run dynamism of exchange rate volatility on exports is significant in order to make short-run adjustments in trade flows.

\section{LITERATURE REVIEW}

\subsection{Conceptual and Theoretical Issues}

Exchange rate is commonly understood to refer to the rate at which a unit of say, country A's currency can be exchanged for a unit of country B's currency. Similarly, Oladipupo and Onotaniyohuwo (2011) defined exchange rate as the price of one country's currency (domestic) in 
terms of another different currency (foreign). It plays a key role in international economic transactions because no nation can operate in isolation as resources of each nation vary in abundance. Generally, the term 'exchange rate' refers to the price of a country's currency expressed in terms of another country's currency.

Exchange rate volatility is usually taken as some measure of the dispersion of the rate over some period of time. Volatility of the rate impacts on growth through a variety of channels, including investment and trade. Interest in exchange rate uncertainty on investment stems from the standard result in option pricing theory, which suggests that the value of an option increases with an increase in the underlying volatility of the stock (Accam, 1997). Also, WiseGEEK (2014) defined exchange rate volatility as "the tendency for foreign currencies to appreciate or depreciate in value, thus affecting the profitability of foreign exchange trades. The volatility is the measurement of the amount that these rates change and the frequency of those changes". There are many circumstances when exchange rate volatility comes into play, including business dealings between parties in two different countries and international investments. Although this volatility is difficult to avoid in such circumstances, the use of futures to lock in exchange rates can mitigate the effects of price change.

Furthermore, volatility can occur in any security that rises or falls in value. It represents the degree to which a variable changes over a period of time. The larger the enormity of a variable change in exchange rate, or the more quickly it changes over time, the more volatile it is. The term is most often used in conjunction with the stock market, but foreign currencies can be volatile as well. When exchange rates are floating exchange rates, as opposed to fixed exchange rates, they are likely to go up and down in value depending upon the strength of the economies involved. As a result, exchange rate volatility is something that affects any business undertaking involving two different countries (see Accam (1997)).

Export is a function of international trade whereby goods produced in one country are shipped to another for future sale or trade (see Investopedia (2014)). The sale of such goods adds to the producing nation's gross output. If used for trade, exports are exchanged for other products or services. Exports are one of the oldest forms of economic transfer, and occur on a large scale between nations that have fewer restrictions on trade, such as tariffs or subsidies (see Investopedia (2014)). Similarly, Joshi (2005) defined export as the shipping of goods and services out of the port of a country. The supplier of such goods and services is referred to as an "exporter" and is based in the country of export whereas the overseas based buyer is referred to as an "importer". In International Trade, "exports" refers to selling goods and services produced in the home country to other countries.

The Cochrane-Orcutt technique requires the transformation of the regression model to a form in which the ordinary least squares procedure is applicable (Cochrane and Orcutt, 1949). Cochrane-Orcutt estimation is a procedure in econometrics, which adjusts a linear model for 
serial correlation in the error term. It is named after statisticians Donald Cochrane and Guy Orcutt (see Wikipedia (2014)).

Some experts, such as Hooper and Kohlhagen (1978), argued that higher exchange rate volatility leads to higher cost of risk-averse traders and less foreign trade. Thus, the exchange rate is agreed on at the time of the trade contract, but payment is not made until the actual delivery of the products or services takes place in the future time. However, when exchange rates become unpredictable, it creates uncertainty about the profits to be made, hence, causing the international trade's benefits to reduce significantly. This shows clearly that volatility depresses international trade.

Some proponents of theoretical models of hysteresis in international trade have shown that increase uncertainty from high volatility in exchange rate can also influence foreign trade in particular if significant sunk cost are involved in international transactions (Baldwin and Krugman, 1989; Dixit, 1989). That is, if exchange rate is high, export will be less. For example, country A that is exporting would be exporting at loss if the exchange rate is high and vice verse.

\subsection{Empirical Literature Review}

The impact of exchange rate on the Nigeria external sector was investigated by Oladipupo and Onotaniyohuwo (2011) using the Ordinary Least Square (OLS) method of estimation for data covering the period, 1970-2008. They found that exchange rate has a significant negative impact on the balance of payments position. The apriori signs of the variables were correctly specified, however, there was the problem of serial correlation as indicated by the value of DW statistics of 1.46. In order to solve the problem, they employed the Cochrane-Orcutt method. The regression equation under the Cochrane-Orcutt method with R-square of 0.99 indicates that $99 \%$ of the variations in the balance of payments are explained by the explanatory variables.

Interestingly, Shalishali and Hadley (2012) studied how major United States (U.S.) exchange partners in rice export namely: Indonesia, Republic of Korea, Nigeria, and Canada and Thailand (as a major competitor of the U.S.) affect the overall U.S. rice export. A two-Stage Least Square method (2SLS) was applied to the U.S. sub-model using historical data. Because of a simple recursive model reflected by its only major competitor, i.e. Thailand, an OLS was applied to each relationship. In the U.S. model, wholesale price of milled rice was an important factor affecting the quantity of milled rice demanded for both food use and brewer. Price of wheat, price of corn, and per capita income were the other factors, as indicated by their significant coefficients. Estimated elasticities of milled rice were inelastic for both rice for food use and beer processing, their result revealed that the elasticities of U.S. milled rice demand with respect to U.S. export price were inelastic (negative) for Korea and Canada but elastic (positive) for Nigeria. They also applied Cochrane-Orcutt Iterative Method to correct for autocorrelation problems.

Moreover, Levich (1978) wrote on efficiency in the foreign exchange market. He used the exchange-market volatility, floating rate period and the results shows an increase in exchange- 
market volatility and the corresponding decrease in the forecasting accuracy of the forward rate. He used the Cochrane-Orcutt procedure to correct for serially correlated residuals. Using the Cochrane-Orcutt procedure did bring the Durbin-Watson statistic to within the acceptable range without significantly changing the parameter estimates or reducing the standard error of the equation. The empirical results however, do provide evidence that if the market is volatile, large profit opportunities are possible. There is no convincing evidence that the market is inefficient.

Also, Wei (1999) estimated a panel of 63 countries of five years interval from 1975, 1980, 1985 and 1990; a total of over 1000 country pairs were examined. Using switching regressions, he found that, for country pairs with large potential trade, exchange rate volatility had a negative and significant effect on bilateral trade among the countries being considered.

Also, Dell'Arricia (1999) examined the effect of exchange rate volatility on the bilateral trade of European Union members and included Switzerland for the period (1975-1994). He used the OLS regression and found that exchange rate volatility had a small but significant negative impact on trade. Also, using both fixed and random effects, the impact of volatility was still negative and significant, but smaller in magnitude. He concluded that elimination of exchange rate volatility would have increased trade by about $3.5 \%$ in 1994 .

Similarly, Rose (2000) obtained comparable results to Dell'Arricia but employing a gravity model. He used 186 countries for five years period of 1970, 1975, 1980, 1985, and 1990, which is similar to Wei (1999). In addition, Rose (2000) results (without random effects) depicts that reducing volatility by one standard deviation would increase bilateral trade by about $13 \%$. Using random effects, the result indicates a small but significant negative effect, implying that, reducing volatility by one-standard deviation would increase bilateral trade by about $4 \%$. However, Tenreyro (2004) cast some doubts on the robustness of Rose (2000) results. Using annual data from 1970-1997 on a sample of 104 countries (including developed and developing), and employed a gravity model that took endogeneity into account, Tenreyro (2004) found that volatility had an insignificant effect on trade. That means volatility does not have effect on trade.

Beside, Hondroyiannis et al. (2005) studied the relationship between exchange rate volatility and aggregate export volumes for 12 industrial economies using a panel data covering the period (1977:1-2003:4). Their results was in contrast to the studies employing panel data, they do not find a single instance in which volatility has a negative and significant impact on trade.

\section{METHODOLOGY}

This section discusses model specification that follow two basic procedure of analysis, viz; Classical Least Square and Cochrane-Orcutt. The data used for the study was obtained through secondary sources. 


\subsection{Model Specification}

Our empirical export demand model is a modify version of Arize et al. (2000), De Vita and Abbott (2004). It can be specified as:

$$
\begin{aligned}
\operatorname{LEXP}_{\mathrm{t}} & =\alpha_{0}+\alpha_{1} \text { LRELP }_{\mathrm{t}}+\alpha_{2} \mathrm{LINC}_{\mathrm{t}}+\alpha_{3} \mathrm{LVOL}_{\mathrm{t}}+\mathrm{e}_{\mathrm{t}} \\
\mathrm{EXP}_{\mathrm{t}} & =\alpha_{0}+\alpha_{1} \mathrm{RELP}_{\mathrm{t}}+\alpha_{2} \mathrm{INC}_{\mathrm{t}}+\alpha_{3} \mathrm{VOL}_{\mathrm{t}}+\mathrm{e}_{\mathrm{t}}
\end{aligned}
$$

Where; $L E X P_{t}$ is defined as the log of real exports; $L R E L P_{t}$ is denoted as relative prices; $I N C_{t}$ is defined as the log of income from our trading partners (foreign income) which is an indicator of potential demand for our exports; LVOL $t$ is denoted as exchange rate volatility that measures uncertainty associated with oscillations in the exchange rate of the Naira ( $N)$ per $(\$)$; $\alpha_{0}$ is a constant; $\alpha_{1}, \alpha_{2}, \alpha_{s}$, are parameters in the model; $e_{t}$ is constant and normally distributed disturbance term. The model depicts that our exports depends on relative prices, income from trading partners and uncertainty connected with exchange rate fluctuations. Therefore, theoretically we expect $\alpha_{1}, \Xi^{2} \alpha_{2}>0$ while the sign of $\alpha_{s}$ is ambiguous. Moreover, equation $1 \& 2$ are very similar except that equation 2 is at level, not in $\log$ form and it follows the same interpretation.

\subsection{Data and Variables Description}

The data was sourced from quantitative publication of the Central Bank of Nigeria, specifically its Statistical Bulletin volume 18 of December, 2007. The variables are generally definite in natural logarithm form (unless otherwise specify). LEXP is log of real exports which are nominal exports deflated using the consumer price index (CPI) as specify in this equation;

$$
L E X P_{t}=\ln \left[\mathrm{EXN}_{\mathrm{t}} / \mathrm{CPI}_{\mathrm{t}}\right]
$$

Interpreted as real exports equal to the natural log of nominal exports (EXN) divided by consumer price index (CPI). Moreover, log of relative prices (LRELP) is an indicator of bilateral trade between two nations which is functional among other variables, two of which are exchange rate and relative price level of two partners (countries). Thus;

$$
\text { LRELP } t=\ln \left[\mathrm{ER}_{\mathrm{t}}^{*} \mathrm{CPI}_{\mathrm{f}} / \mathrm{CPI}_{\mathrm{n}}\right]
$$

$\mathrm{ER}_{\mathrm{t}}$ is defined as the naira/dollar exchange rate, multiple by a fraction of consumer price index of foreign nations $\left(\mathrm{CPI}_{\mathrm{f}}\right)$ divided by consumer price index of Nigeria $\left(\mathrm{CPI}_{\mathrm{n}}\right)$. Due to problems of getting CPI of so many trade partners of Nigeria and computational aggregation we took equation (3) as a proxy to equation (4), as follows;

$$
\text { LRELP }{ }_{t}=\ln \left[\mathrm{ER}^{*} \mathrm{CPI}_{\mathrm{n}}\right]
$$

$L I N C$, defined as log of foreign income of net capital flow of UK, USA, Western Europe and other countries as a measure of income for Nigerian trading partners. Finally, log of exchange rate volatility $\left(\mathrm{LVOL}_{t}\right)$ is a variable that measures uncertainty encountered by exporter as a result of unpredictable spiral or oscillations in the exchange rates. This term is highly controversial according to the literature (Bollerslev, 1986; McKenzie and Brooks, 1997). Therefore, we used simple moving average of the growth rate of both nominal and real exchange rate. 


\section{EMPIRICAL RESULTS}

To evaluate the effects of LRELP, LINC, and LVOL on LEXP, with logarithm and without, we present the empirical results of the classical least square estimates of the export equations in Table 1, which is separated into model 1 and 2. From the estimated export function the values of coefficients of LRELP, LINC, and LVOL represent their parameters. The intercepts of the two equations exert positive relationship with the dependent variable and they are all significant at $1 \%$ level of significance.

The relationship between relative prices and dependent variable is negative and the coefficient of LRELP is statistically significant at $1 \%$. This inverse relationship is in contradiction with the apriori expectation. This implies that, a percentage increase in relative price leads to decrease in exports by $(-50.1 \%)$, in a real life situation. It further means that, a unit increase in the price of producers' goods leads to decrease in production of more units of that product and it also indicate decline in the demand of Nigerian exports. Thus, this goes a long way in deflating Nigerian foreign reserve. Hence, this is not consistent with economic theory. But, model 2 is in line with the theory and is statistically significant at $5 \%$ level of significance. Therefore, it will raise the value by $5.67 \%$ and boost Nigerian foreign reserve in her trading partner's countries which could be used to sponsor importation of goods for some years in the future. The coefficient of foreign income in our trading partners (LINC) shows a positive relationship with dependent variable which is consistent with the theory. This positive change in foreign income which might be channeled to investment in Nigeria will certainly expand Nigeria's export sector. It is statistically significant at $1 \%$ level of significance with t-ratio of 2.97 . This implies that $1 \%$ increase in foreign income within the years understudy leads to $11 \%$ increase of Nigerian export. This means as foreign income (LINC) increases by a unit, export (LEXP) will increase by $11 \%$, the variables are directly related. The story is the same in model 2, except that EXP will make very small increase by $0.00394 \%$.

Table-1. Classical Least Square Estimates of the Export Equations

\begin{tabular}{l|l|l}
\hline Variable & $\begin{array}{l}\text { Model 1 } \\
\text { Dependent variable: LEXP }\end{array}$ & $\begin{array}{l}\text { Model } 2 \\
\text { Dependent variable: EXP }\end{array}$ \\
\hline Constant & $1.36^{* *}(5.02)$ & $2.47 * * *(10.94)$ \\
\hline LRELP & $-0.501^{* * *}(-2.81)$ & \\
\hline RELP & \multicolumn{2}{c}{$0.06^{* *}(2.35)$} \\
\hline LINC & $0.11^{* *}(2.97)$ & \\
\hline INC & & $3.94 \mathrm{E}-05 * * *(2.9)$ \\
\hline ma_LVOL & $0.08^{* * *}(2.96)$ & \\
\hline ma_VOL & & $-2.03 \mathrm{E}-06(-0.45)$ \\
\hline R-square & 0.61 & 0.55 \\
Adj. R-square & 0.58 & 0.51 \\
F-statistic & 17.22 & 13.25 \\
D.W. statistic & $1.43+$ & $1.20 \#$ \\
\hline
\end{tabular}

Note: t-statistics are in parenthesis.

*** significant at $1 \%$; ** significant at $5 \%$; significant at $10 \%$.

+ Denotes autocorrelation decision is inconclusive at $5 \%$.

\# Denotes the presence of autocorrelation at $5 \%$. 
Similarly, the coefficient of volatility, 0.08 in Model 1, is positively related to dependent variable and statistically significant at $5 \%$ level of significance. This implies that, a $1 \%$ increase in volatility, a unit change in naira - dollar exchange rates may lead to $8 \%$ increase in exports. Thus, indicates positive effect on Nigerian export (a 1\% rise in ma_LVOL raises LEXP to 8\%). When we compare it with coefficient of ma_VOL in Model 2, the result is negative and insignificant at any level of significance.

The measure of goodness of fit, R-square is 0.61 which can be interpreted as $61 \%$ and when adjusted for degree of freedom it declines to $58 \%$ in Model 1, while Model 2 depicts a similar pattern but is lesser, $55 \%$ and $51 \%$ respectively. In Model 1, Durbin-Watson (D.W.) statistics is 1.43 signifying that the test for autocorrelation is within the inconclusive region, while there is evidence of autocorrelation in Model 2 with D.W. statistic of 1.20. Also in Model 1, the F-statistic of 17.22 is greater than $2.92\left(\mathrm{~F}^{*}>\mathrm{F}^{\alpha}\right)$ the null hypothesis is therefore rejected that, the slope coefficients are simultaneously different from zero. Similarly, the overall significance of all the parameters is not equal to zero in Model 2. Hence, we can say that, Model 1 is more robust and better than Model 2 in Table 1.

In a same fashion, Table 2 present two sets of empirical results of the Cochrane-Orcutt estimate of the export Models. The coefficients of the two slopes (i.e. $\alpha$ ) are positively related to the dependent variable and both are statistically significant at $1 \%$ level of significance in both Model 3 and 4 . Thus, a unit rise will lead to $143 \%$ and $403 \%$ rise in exports respectively.

Table-2. Cochrane-Orcutt Estimates of the Export Equations

\begin{tabular}{|c|c|c|}
\hline Variable & $\begin{array}{l}\text { Model } 3 \\
\text { Dependent variable: LEXP }\end{array}$ & $\begin{array}{l}\text { Model } 4 \\
\text { Dependent variable: EXP }\end{array}$ \\
\hline Constant & $\begin{array}{l}1.43^{* * * *} \\
(4.48)\end{array}$ & $\begin{array}{l}4.03 \text { *** } \\
(7.04)\end{array}$ \\
\hline LRELP & $\begin{array}{l}-0.44^{* * * *} \\
(-2.24)\end{array}$ & \\
\hline RELP & & $\begin{array}{l}-0.07 \\
(-1.51)\end{array}$ \\
\hline LINC & $\begin{array}{l}0.08 * * \\
(2.09)\end{array}$ & \\
\hline INC & & $\begin{array}{l}3.44 \mathrm{E}-05 \\
(1.52)\end{array}$ \\
\hline ma_LVOL & $\begin{array}{l}0.08 \text { ** } \\
(2.65)\end{array}$ & \\
\hline ma_VOL & & $\begin{array}{l}5.54 \mathrm{E}-07 \\
(0.12)\end{array}$ \\
\hline $\begin{array}{l}\text { R-square } \\
\text { Adj. R-square } \\
\text { F-statistic } \\
\text { D.W. statistic }\end{array}$ & $\begin{array}{l}0.65 \\
0.62 \\
8.48 \\
2.0\end{array}$ & $\begin{array}{l}0.67 \\
0.64 \\
1.09 \\
2.20\end{array}$ \\
\hline
\end{tabular}

The coefficients of relative prices are both negative in the two Models ( 3 and 4), but Model 3 is significant at $1 \%$, while it is insignificant in Model 4 . This implies that, $1 \%$ increase of relative 
prices (LRELP) will lead to $-44 \%$ decrease in exports (LEXP) and also $1 \%$ rise in relative prices (RELP) will result in the fall of exports (EXP) by $-7 \%$ in Model 3 and 4 respectively. This inverse relationship contradicts the theory as relative prices of exports increases, volume of exports also increases, terms of trade would be elastic, and balance of trade exhibits improvement. A fall in relative prices would not encourage exports but does discourage it. The explanation that could be offered here is that, during and after the structural adjustment program (SAP) era of 1986 exchange rate worsens and thereby affected the relative prices. As we all know price level is a macro phenomenon and would eventually influence other macro variables and would directly harm exports. Up till 2014 prices did not return to their pre-SAP levels.

Furthermore, the coefficients of foreign income (LINC) and exchange rate volatility variables are both positive and significant at $5 \%$ level of significance in Model 3 while Model 4 shows the absence of both scenarios. The implication is that a unit rise in foreign income (LINC) by $1 \%$ leads to the rise of exports (LEXP) by 8\%. Additionally, exchange rate trade volatility does affect aggregate trade positively as can be seen in Table 2 . An increase of volatility index (ma_LVOL) by $1 \%$ leads to the increase in exports (LEXP) by $8 \%$; any unit rise of volatility index raises aggregate trade eightfold. These results are statistically significant at $5 \%$ level. One unique discovery is that, the coefficient values of foreign income (LINC) and volatility (ma_LVOL) are statistically the same (i.e. 0.08).

Still, on the volatility index, the values of the coefficients are the same in both Model 3 and Model 1 in Table 2 and 1 respectively, but with different levels of confidence. An explanation that could be given is that as uncertainty associated with exchange rate increases, exporters would be ready to export eight-fold so as to over shadow the volatility and derive maximum benefit from trade.

Interestingly, the adjusted value of the coefficients of multiple determinations from Model 3 is $65 \%$ which is statistically indistinguishable from that of Model 4. This suggests a high degree of explanatory power of the independent variables. To correct the serial correlation problem in Table 1, that shows Durbin-Watson (DW) test result of 1.43 in the OLS estimation, the Cochrane-Orcutt model was applied and I found the DW test to be 2.0 in Model 3 and 2.20 in Model 4, which revealed the absence of autocorrelation at $5 \%$ level of significance in both Models. Therefore, we can rightly say that, Model 3 is more robust and explains the situation better than all the Models in this study. In summary, the positive sign of the intercepts variables in all the four Models in this paper explains that the variables exert positive influence on the level of aggregate export. An explanation that could be offered for all these were the impact of such positive factors as increase in the exports of groundnut, 'Groundnut Pyramid' of 1960s and 1970s, boost in crude oil exports, the establishment of export processing zones in the six geo-political regions and so on. 


\section{CONCLUSION AND FURTHER RESEARCH}

From the foregoing discussions, it is obvious that Nigerian exports from 1970 to 2007 were determined by Naira exchange rate volatility, foreign income and relative prices. I discovered that exchange rate volatility and foreign income have positive and significant effect on exports (see Model 3). The implications are that, a unit rise in exchange rate volatility and foreign income lead to increase in exports both by $8 \%$. They both raises aggregate trade eightfold. While, relative prices exert negative and significant effect on exports trade in the country (see Model 3). Therefore, on exchange rate volatility this work is consistent with Hondroyiannis et al. (2005), Tenreyro (2004) and Levich (1978). It is inconsistent with results of Dell'Arricia (1999), Wei (1999), Rose (2000), Oladipupo and Onotaniyohuwo (2011) and Elbadawi et al. (2012).

A plausible explanation is that, minimal exchange rate volatility may spur exports, because exporters would like to over shadow the volatility and derive maximum benefit from trade.

Thus, high exchange rate variability could be managed to keep it low. Consequently, this research suggest that government and the private sector should invest more facilities so as to transform natural resources to semi-processed products to add value to Nigerian exports thereby improving both exports value and volume, accordingly, improving terms of trade as well as balance of trade of the country. Again, export promotion strategy should focus on the development of regional markets within the country. Additionally, mass production should be given attention via all sectors of the economy, such as agricultural produce, solid minerals, among others. This would reduce unemployment and boost foreign reserve of the country.

To promote agricultural produce, farmers can be encouraged by mechanized farming, modernizing their products and improve packaging system for exports. Also, bilateral trade could be encouraged by the government by signing trade agreements with countries that need our farm produce, such as; tomatoes, onions, Irish potatoes, garlic, hide and skin, live and dress meat, cotton, groundnut, rubber, etc.

Finally, further research can look at more complex models to study short run dynamics and long run equilibrium analyses of this theme so as to adequately inform the policy makers on promoting exports, strengthening the Naira to minor spirals among other things.

Funding: This study received no specific financial support.

Competing Interests: The authors declare that they have no conflict of interests.

Contributors/Acknowledgement: The author thanks TET Fund Nigeria for financial support, Federal University Dutse for facilitation of the grant and Mr. Itari Abdulrazak Rilwan for his useful suggestions.

\section{REFERENCES}

Accam, B., 1997. Survey of measurement of exchange rate instability. London: Cassel Publisher.

Arize, A.C., T. Osang and D.J. Slottje, 2000. Exchange rate volatility and foreign trade: Evidence from thirteen LDCs. Journal of Business and Economic Statistics, 18(1): 10-17. 
Baldwin, R. and P. Krugman, 1989. Persistent trade effects of large exchange rate shocks. Quarterly Journal of Economics, 104(4): 635-665.

Bollerslev, T., 1986. Generalised autoregressive conditional heteroscedasticity. Journal of Econometrics, 31(3): 307-323.

CBN, 2012. Statistical bulletin, various issues (2007-2012), published by the Central Bank of Nigeria.

CBN, 2013. Annual reports and statement of accounts, various issues (2010-2013), published by the Central Bank of Nigeria.

Cochrane, D. and G.H. Orcutt, 1949. Application of least squares regression to relationships containing auto-correlated error terms. Journal of the American Statistical Association, 44(245): 32-61. DOI 10.1080/01621459.1949.10483290.

De Vita, G. and A. Abbott, 2004. The impact of exchange rate volatility on UK exports to EU countries. Scottish Journal of Political Economy, $51(1): 62-81$.

Dell'Arricia, G., 1999. Exchange rate fluctuations and trade flows: Evidence from the European union. IMF Staff Papers, 46(3): 315-334.

Dixit, A., 1989. Hysteresis, import penetration and exchange-rate pass-through. Quarterly Journal of Economics, 104(2): 205-227.

Doroodian, K., 1999. Does exchange rate volatility deter international trade in developing countries. Journal of Asian Economics, 10(3): 465-474.

Elbadawi, I.A., L. Kaltani and R. Soto, 2012. Aid, real exchange rate misalignment and economic growth in Sub-Saharan Africa. World Development, 40(4): 681 - 700.

Goldberg, M.D. and R. Fryman, 1993. Empirical exchange rate models and shifts in the co-integrating vector. Economic Research Reports. CV Starr Centre for Applied Economics, New York University.

Hondroyiannis, G., P.A.V.B. Swamy, G. Tavlas and M. Ulan, 2005. Some further evidence on exchange-rate volatility and exports. Working Paper, No. 28, Bank of Greece.

Hooper, P. and S.W. Kohlhagen, 1978. The effect of exchange rate uncertainty on the prices and volume of international trade. Journal of International Economics, 8(4): 483-511.

Investopedia, 2014. Export. Available from http://www.investopedia.com/terms/e/export.asp [Accessed $1 / 11 / 2014]$.

Joshi, R.M., 2005. International marketing. New Delhi and New York: Oxford University Press. ISBN. 0-19567123-6.

Krugman, P., 1989. Exchange rate instability: The lionel robbins lectures. Cambridge: The Massachusetts Institute of Technology (MIT) Press.

Levich, R.M., 1978. Further results on the efficiency of markets for foreign exchange. Federal Reserve Bank of Boston, Conference Series, No. 20.

McKenzie, M.D. and R. Brooks, 1997. The impact of exchange rate volatility on German-U.S. trade flows. Journal of International Financial Markets, Institutions and Money, 7(1): 73-87. 
Obaseki, P.J., 2001. The purchasing power parity measure of Naira's equilibrium exchange rate. CBN Economic and Financial Review, 36(1): 1-21.

Oladipupo, A.O. and F.O. Onotaniyohuwo, 2011. Impact of exchange rate on balance of payment in Nigeria. African Research Review, 5(4): $73-88$.

Rose, A., 2000. One money, one market: Estimating the effect of common currencies on trade. Economic Policy Review, 15(30): 8-45.

Shalishali, M.K. and L.U. Hadley, 2012. A test of factors affecting the U.S. rice export: an econometric modeling using U.S. world partners and one major competitor. Journal of International Business Research, 1. Available from http://www.freepatentsonline.com/article/Journal-InternationalBusiness-Research/179817829.html.

Soludo, C.C. and F.A. Adeola, 1997. Exchange rate misalignment and investment in Nigeria. Paper Presented to OECD Development Centre, Paris.

Tenreyro, S., 2004. On the trade impact of nominal exchange rate volatility. Federal Reserve Bank of Boston, Working Paper No. 2-3.

Wei, S.J., 1999. Currency hedging and goods trade. European Economic Review, 43(7): 1371-1394.

Wikipedia,

$2014 . \quad$ Cochrane-orcutt estimation.

Available

from

http://en.wikipedia.com/Cochrane_Orcutt_Estimation.

WiseGEEK, 2014. What is exchange rate volatility. Available from http://www.wisegeek.com/what-isexchange-rate-volatility.htm [Accessed 1/11/2014].

\section{Appendix}

Model-1. OLS, using observations 1972-2007 ( $\mathrm{T}=36)$ Dependent variable: 1_EXPt

\begin{tabular}{l|l|l|l|l|l}
\hline & Coefficient & Std. Error & t-ratio & p-value & \\
\hline const & 1.35911 & 0.270988 & 5.0154 & 0.00002 & $* * *$ \\
\hline l_RELP & -0.500517 & 0.177857 & -2.8141 & 0.00830 & $* * *$ \\
\hline l_INC & 0.108479 & 0.0365593 & 2.9672 & 0.00565 & $* * *$ \\
\hline ma_l_VOL & 0.0831408 & 0.0280974 & 2.9590 & 0.00577 & $* * *$ \\
\hline
\end{tabular}

\begin{tabular}{l|l|l|l|l}
\hline Mean dependent var & 1.144697 & & S.D. dependent var & 0.217862 \\
\hline Sum squared resid & 0.635501 & & S.E. of regression & 0.140923 \\
\hline R-squared & 0.617451 & & Adjusted R-squared & 0.581587 \\
\hline F(3, 32) & 17.21650 & & P-value $(\mathrm{F})$ & $7.77 \mathrm{e}-07$ \\
\hline Log-likelihood & 21.58170 & & Akaike criterion & -35.16341 \\
\hline Schwarz criterion & -28.82933 & & Hannan-Quinn & -32.95264 \\
\hline rho & 0.247976 & & Durbin-Watson & 1.426176 \\
\hline
\end{tabular}


Model-2. OLS, using observations 1972-2007 $(\mathrm{T}=36)$ Dependent variable: EXPt_Nm_

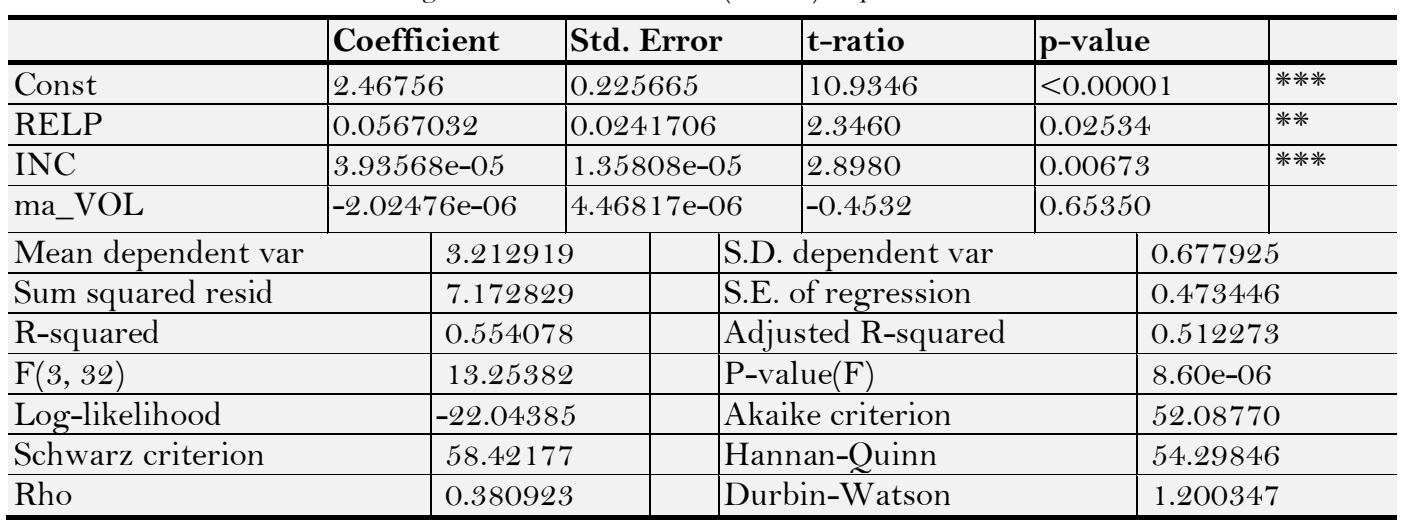

Model-3. Cochrane-Orcutt, using observations 1973-2007 (T = 35) Dependent variable: 1_EXP

\begin{tabular}{l|l|l|l|l|l}
\hline & Coefficient & Std. Error & t-ratio & p-value & \\
\hline const & 1.42521 & 0.318147 & 4.4797 & 0.00009 & $* * *$ \\
\hline l_RELP & -0.436714 & 0.195412 & -2.2348 & 0.03277 & $* *$ \\
\hline l_INC & 0.0796724 & 0.0381101 & 2.0906 & 0.04486 & $* *$ \\
\hline ma_l_VOL & 0.0829474 & 0.0313614 & 2.6449 & 0.01271 & $* *$ \\
\hline
\end{tabular}

Statistics based on the rho-differenced data:

\begin{tabular}{l|l|l|l|l}
\hline Mean dependent var & 1.154636 & & S.D. dependent var & 0.212600 \\
\hline Sum squared resid & 0.532814 & & S.E. of regression & 0.131101 \\
\hline R-squared & 0.653925 & & Adjusted R-squared & 0.620434 \\
\hline $\mathrm{F}(3,31)$ & 8.476637 & & P-value $(\mathrm{F})$ & 0.000294 \\
\hline rho & -0.001989 & & Durbin-Watson & 1.995298 \\
\hline
\end{tabular}

Model-4. Cochrane-Orcutt, using observations 1973-2007 ( $\mathrm{T}=35)$ Dependent variable: EXPt_Nm_

\begin{tabular}{l|l|l|l|l|l}
\hline & Coefficient & Std. Error & t-ratio & p-value & \\
\hline const & 4.0325 & 0.572589 & 7.0426 & $<0.00001$ & $* * *$ \\
\hline RELP & -0.0648088 & 0.0428654 & -1.5119 & 0.14068 & \\
\hline INC & $3.43805 \mathrm{e}-05$ & $2.25899 \mathrm{e}-05$ & 1.5219 & 0.13816 & \\
\hline ma_VOL & $5.54185 \mathrm{e}-07$ & $4.71758 \mathrm{e}-06$ & 0.1175 & 0.90724 & \\
\hline
\end{tabular}

Statistics based on the rho-differenced data:

\begin{tabular}{l|l|l|l|l}
\hline Mean dependent var & 3.241331 & & S.D. dependent var & 0.665721 \\
\hline Sum squared resid & 5.042604 & & S.E. of regression & 0.403317 \\
\hline R-squared & 0.667397 & & Adjusted R-squared & 0.635210 \\
\hline F $(3,31)$ & 1.088474 & & P-value(F) & 0.368540 \\
\hline rho & -0.101686 & & Durbin-Watson & 2.197679 \\
\hline
\end{tabular}

Views and opinions expressed in this article are the views and opinions of the author(s), International Journal of Management and Sustainability shall not be responsible or answerable for any loss, damage or liability etc. caused in relation to/arising out of the use of the content. 